Research Article

Animal Genetics

\title{
Use of DNA barcode in the identification of fish eggs in tributaries of the Paranapanema River basin
}

\author{
Moema Cristina Costa de $\operatorname{Lima}^{1}$ (D), Same Costa $\operatorname{Lima}^{1}$ (D), Camila Satie Savada ${ }^{1}$ (D), Karen Mayumi \\ Suzuki $^{1}$ (D), Mário Luís Orsi ${ }^{2}$ and Fernanda Simões de Almeida ${ }^{1}$ (D) \\ ${ }^{1}$ Universidade Estadual de Londrina, Departamento de Biologia Geral, Laboratório de Genética e Ecologia \\ Animal, Londrina, PR, Brazil. \\ ${ }^{2}$ Universidade Estadual de Londrina, Departamento de Biologia Animal e Vegetal, Laboratório de Ecologia \\ de Peixes e Invasões Biológicas, Londrina, PR, Brazil.
}

\begin{abstract}
Fish eggs are often excluded from identification analysis since at this stage of development there are few morphological characters. The correct identification of eggs can provide important information about spawning areas of species. The current work aimed to identify fish eggs in the Tibagi and Cinzas Rivers using the DNA barcode to obtain information on richness and diversity, adding to the existing data in the area. Of the 928 sequences analyzed using the BOLD Systems database, $99.78 \%$ were able to be identified at a specific level, demonstrating a high success rate for egg identification. The samples resulted in 25 species, 11 families, and 2 orders. Of the 25 species found, more than half $(60 \%)$ present reproductive migration behavior, indicating that the tributaries of the Capivara reservoir are being used as a migratory route by these species. Eggs of rare and endangered species were found, indicating these tributaries as spawning grounds for these species. The results demonstrate the importance of identifying fish eggs in reservoir-influenced environments to recognize breeding areas of native and endangered species, as well as the importance of the Tibagi and Cinzas Rivers for the maintenance of native fish species in the Paranapanema River.
\end{abstract}

Keywords: Reservoirs, conservation, freshwater, Neotropical, COI, ichthyoplankton.

Received: October 14, 2019; Accepted: May 08, 2020.

\section{Introduction}

Despite great diversity, freshwater ecosystems are one of the most threatened natural environments (Dudgeon et al., 2006; Strayer and Dudgeon, 2010). Among the threats are destruction and degradation of habitat and the construction of reservoirs (Lévêque et al., 2008; Geist, 2011). Dams are one of the main threats to biodiversity in freshwater environments due to the inability of some species to survive in dammed water bodies, as a result of loss of breeding habitats, impairment in reproductive migration, and population fragmentation. In addition, dams provide greater water transparency, allowing greater predation of fish eggs, larvae, and juveniles (Agostinho et al., 2007).

The Paranapanema River, one of the main tributaries of the Paraná River (Orsi et al., 2016), currently includes 11 hydroelectric plants along its main channel in a cascade reservoir system. The main tributaries of the Capivara reservoir are the Tibagi and Cinzas Rivers, considered important for

Send correspondence to Fernanda Simões de Almeida. Universidade Estadual de Londrina, Departamento de Biologia Geral, Laboratório de Genética e Ecologia Animal, Rodovia Celso Garcia Cid, PR 445 km 380, 86057-970, Londrina, PR, Brazil. E-mail: fernandasa@uel.br. maintaining the biodiversity of local ichthyofauna. As these rivers are lotic environments and similar to the original basin, they offer adequate conditions that aid in the maintenance of species (Dias et al., 2004; Hoffmann et al., 2005; Agostinho et al., 2007; Lopes et al., 2007; Vianna and Nogueira, 2008; Orsi, 2010).

In fact, identification, distribution, and abundance of ichthyoplankton are useful for identifying spawning places and migration routes in areas influenced by reservoirs (Nakatani et al., 1997). However, the classification of these reproductive products is extremely complex, as many of their morphological characters are not yet sufficiently developed to be analyzed (Pegg et al., 2006; Ward et al., 2009). The task is even more problematic for eggs, due to their small size and similarity between different species. Therefore, identification using morphological characters does not include this stage, precisely because, in most cases, it is impossible to identify species (Richards, 2005).

The use of molecular markers to correctly discriminate species has become extremely important, among the molecular tools available, the technique proposed by Hebert et al. (2003) known as the DNA barcode method. One of the great advantages of this technique in resolving species from 
ichthyoplankton is that it can be applied to organisms at different stages of their life cycle, including eggs (Stoeckle, 2003). Some studies have already demonstrated the efficiency of the technique in identifying fish eggs and larvae (Hubert et al., 2008; Gleason and Burton, 2012; GarcíaDávila et al., 2014, 2015; Rodrigues et al., 2018). FrantineSilva et al. (2015) and Lima (2015) when identifying ichthyoplankton using the DNA barcode technique in Paranapanema river reservoirs, observed that the Capivara presented the highest species richness when compared to the other reservoirs, as well as its main tributaries, the Tibagi and Cinzas Rivers.

Due to the greater richness of species found in previous studies, the present study aims to identify fish eggs collected in three consecutive reproductive cycles (piracema periods 2012-2015) in the Tibagi River and Cinzas River using the DNA barcode technique, in order to obtain more information on the estimation of drifting eggs as well as the spawning grounds for fish species.

\section{Material and Methods}

\section{Egg sampling and screening}

Sampling was performed in two main tributaries of the Parapanema river, the Tibagi River and the Cinzas River, during three reproductive periods of fish (piracema) (Octo- ber 2012 to March 2013, September 2013 to March 2014, and September 2014 to March 2015). In every piracema, monthly collections were carried out at each of the locations. The study points in the Tibagi river basin were represented by its sub-tributary, the Congonhas River, and the lower portion of its main channel, and the points in the Cinzas River basin were the middle and lower portions of its main channel (Figure 1).

For sampling, two conical nets with a $0.5 \mathrm{~mm}$ mesh, $1.6 \mathrm{~m}$ in length were used, remaining approximately $20 \mathrm{~cm}$ below the water surface. In each sampling, three repetitions of ten minutes were performed. The collected samples were immediately deposited in $98 \%$ alcohol and then stored at -20 ${ }^{\circ} \mathrm{C}$. In the laboratory, the collected samples were screened using a stereoscopic magnifying glass. After pre-classification, samples were randomly selected to reach the greatest variety of egg morphotypes per sampling event, and subsequently photo-registered and individualized for further genetic analyses (Figure S1). The protocol was approved by the Ethics Committee of the State University of Londrina CEUA/UEL (CEUA n ${ }^{\circ}$ 29790.2012.39).

DNA extraction, amplification, and sequencing of the 5 ' region of the $\mathrm{COI}$ gene

For total DNA extraction, each egg was placed in a 96 well plate (microtiter plates) and extraction was performed

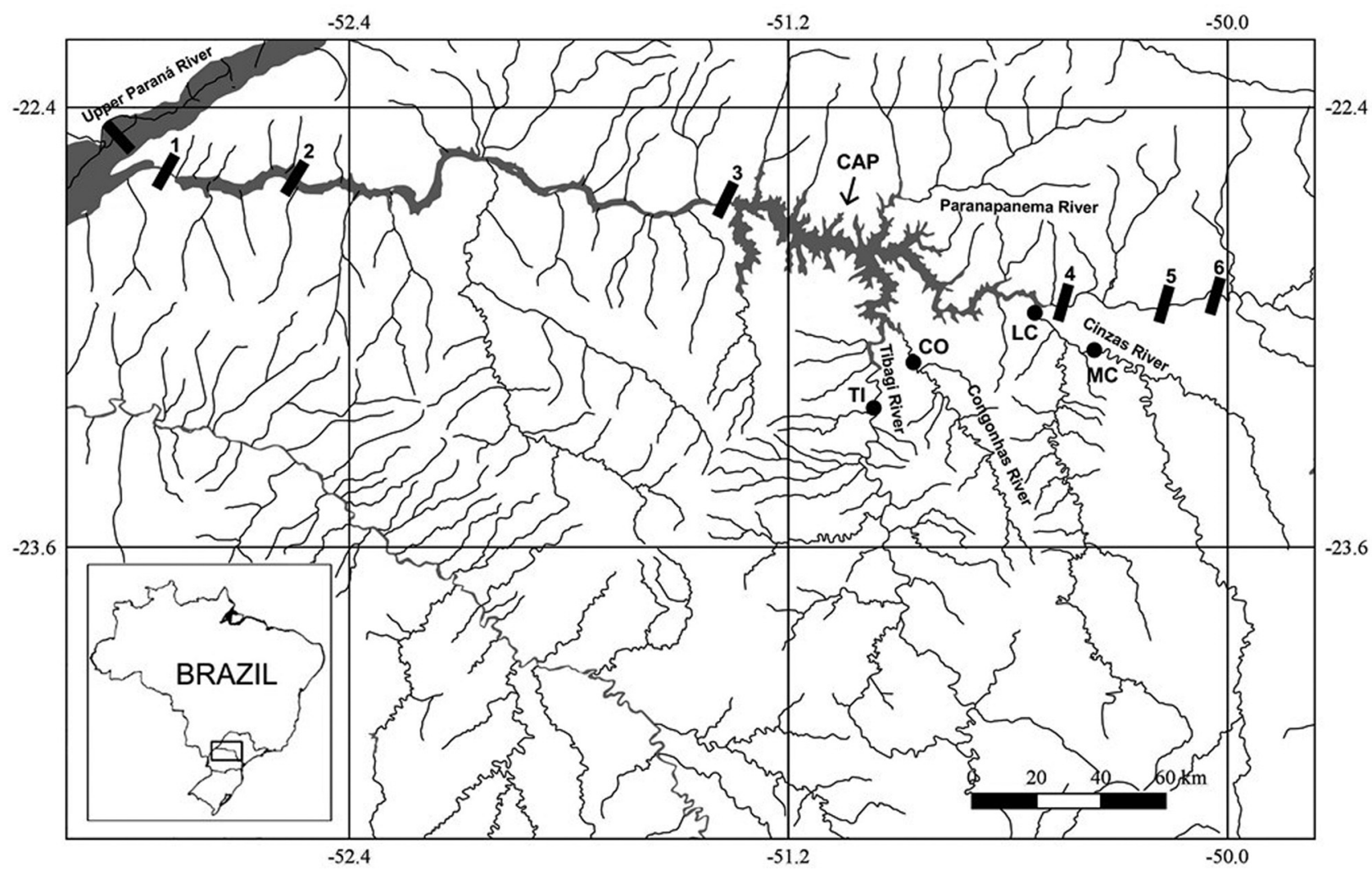

Figure 1 - Distribution of sampling points along the lower-middle stretch of the Paranapanema River basin. CAP: Capivara reservoir, TI: Tibagi River, CO: Congonhas River, LC: lower Cinzas River, and MC: middle Cinzas River. The numbers represent the locations of the dams: (1) Rosana; (2) Taquaruçu; (3) Capivara; (4) Canoas I; (5) Canoas II; (6) Salto Grande. 
using Chelex100 solution (BIO-RAD) and Proteinase K (Invitrogen) according to the methodology described by Frantine-Silva et al. (2015). Amplification of the 5' region of the COI gene was carried out according to Frantine-Silva et al. (2015), using the primers FishF1 5'-TCAACCAACC ACAAAGACATTGGCAC-3' and FishR1 5'-TAGACTT CTGGGTGGCCAAAGAATCA-3' (Ward et al., 2005). The purified samples were sequenced in $10 \mu \mathrm{L}$ reactions containing $1 \mu \mathrm{L}$ Big Dye buffer, $2 \mu \mathrm{L}$ Big Dye Terminator v. 3.1. Cycle Sequencing (Applied Biosystems, CA, USA), $0.25 \mu \mathrm{L}$ of primer FishF1 $(20 \mu \mathrm{M})$, and water to complete the volume. Reaction products were sequenced in an ABIPRISM 3500 XL automatic sequencer (Applied Biosystems).

\section{Data analysis}

The COI sequences were obtained only from the forward band, which was larger than $600 \mathrm{bp}$ and the quality of the sequences was verified using the online application Electropherogram Quality Analysis (Togawa and Brígido, 2003), available at (http://asparagin.cenargen.embrapa.br/phph/). Next, alignment of the sequences was performed using the MUSCLE application (Edgar, 2004) in the MEGA program, v6.0 (Tamura et al., 2013).

All sequences were submitted to the BOLD database (Ratnasingham and Hebert, 2007), (http://www.boldsystems.org/), to verify the correspondence and similarity of the submitted sequences with those stored in the database. The sequences deposited with the best matches for each taxon $(>99 \%)$, together with the sequences of the samples analyzed, were incorporated into the intraspecific and interspecific genetic distance analyses based on the Kimura-2-Parameters evolution model (K2P) (Kimura, 1980), which was chosen as it presents better performance when genetic distances are low (Nei and Kumar, 2000; Hebert et al., 2003), as is the case of comparisons between species. Samples with low interspecific genetic divergence values $(<2 \%)$ compared to sequences deposited with BOLD Systems were defined at species level and samples with intraspecific genetic divergence greater than $(2 \%)$ were defined at genera and family level.

The same model was applied for the construction of a genetic distance tree using the Neighbor-Joining (NJ) method, aiming to obtain a graphical representation of the distribution of genetic distances between taxa. Distance analysis and identification of the second taxon with the shortest interspecific distance (nearest neighbor) as well as the Neighbor-Joining tree were performed using the MEGA v6.0 program (Tamura et al., 2013). The sequences obtained were deposited in BOLD Systems, available at: BOLD projects: CAPV (Accession nos. CAPV001-17 to CAPV92817).

\section{Results}

\section{Molecular identification and genetic distance}

A total of 928 sequences were obtained, with approximately $600 \mathrm{bp}$ after the final alignment. Based on the similarity between the sample sequences and the sequences available in the database, it was possible to identify 926 of the 928 eggs analyzed (99.78\%) at species level, with a mean similarity $>99 \%$. Of the 928 eggs analyzed, 528 came from the Cinzas River tributary and 400 from the Tibagi River.

Analysis of the similarity of the sequences resulted in 2 orders, 11 families, 18 genera, and 25 species. Among the 928 samples, 274 were distributed in 16 species of the order Characiformes (64\%) and 654 in 9 species of the order Siluriformes (36\%). Only 2 specimens could be discriminated only at family level, with a mean similarity of $(91.62 \%)$, both represented by the family Heptapteridae (Table S1).

All 25 species identified are present in the list of documented species for the Paranapanema River, thus representing $11.1 \%$ of a total of 225 species described for the Paranapanema River. The amplified fragments had a mean of 600 bp, with good quality, and no evidence of insertions, deletions, or stop codons. The distances based on K2P demonstrated that intraspecific distances were $<1 \%$, with a minimum distance of $0 \%$ and a maximum of $0.51 \%$.

The compressed NJ-K2P tree points to a short distance between specimens identified at the species level and vouchers taken from the BOLD Systems $(<1 \%)$, as well as high branch sustainability indices (Figure 2). Distance analysis to the nearest taxon (DVP) was performed to measure the distance between related taxa. The shortest DVP distance was observed between Megaleporinus obtusidens and Megaleporinus piavussu $(\mathrm{D}=4.59 \pm 0.90)( \pm 1)$.

\section{Taxonomic abundance and composition of sampled eggs}

Regarding the two main tributaries studied, the lower Cinzas River presented the largest number of species (20), while the Tibagi River presented the lowest number (11) (Table 1). Among the 20 species found in the lower Cinzas River, Pimelodus maculatus (219), Pimelodus microstoma (74), Leporinus friderici (44), Sorubim lima (32), and Megaleporinus macrocephalus (18) were the most abundant. Of the 11 species found in the Tibagi River, Pimelodus maculatus (138), Leporinus friderici (98), Pimelodus sp (73), Pimelodus microstoma (38), and Pinirampus pirinampu (16) were the most abundant. The Congonhas River presented only one species Triportheus nematurus (23) (Table 1).

When comparing the two tributaries studied, the highest richness was found for the Cinzas River, with 21 taxonomic units, which represented $84 \%$ of the species identified at specific level (Figure 3). Among the captured species, we observed the presence of Pseudopimelodus mangurus, a rarely captured species, categorized as vulnerable and the species Pseudoplatystoma corruscans, categorized as near threatened. 


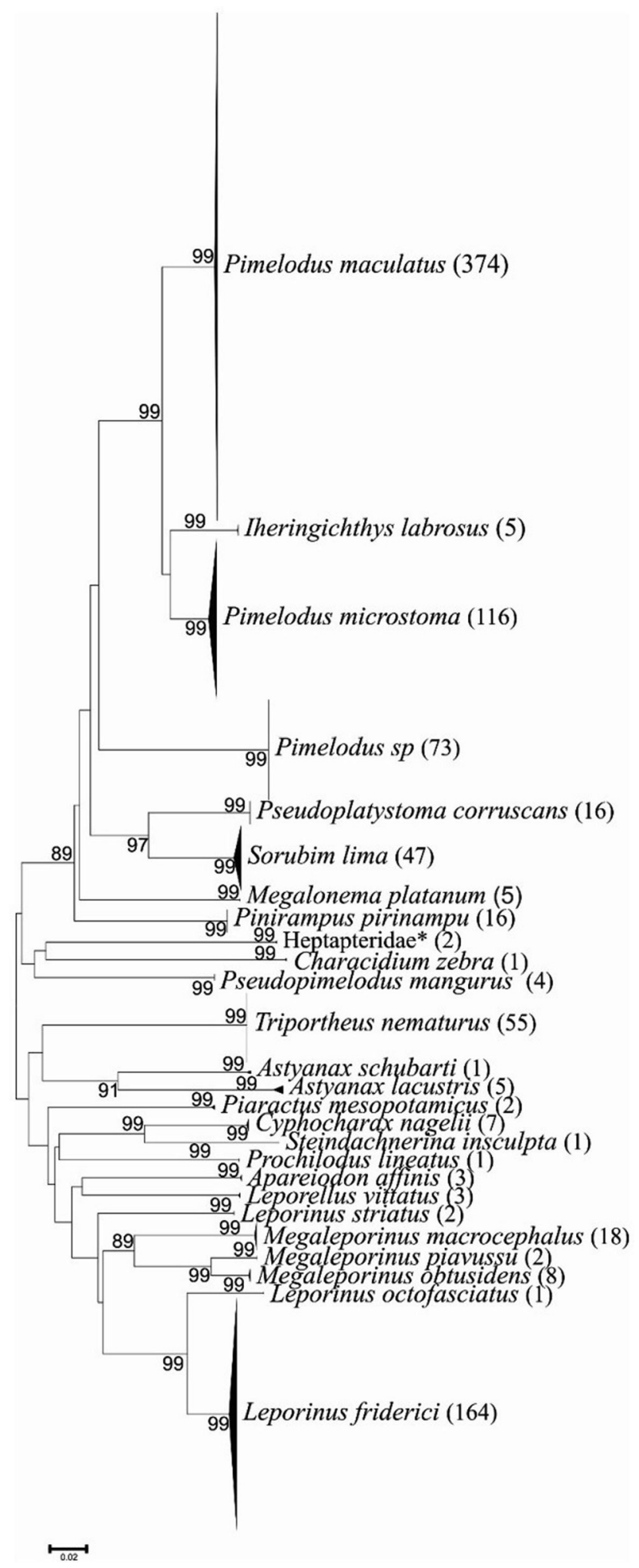

Figure 2 - Dendrogram of genetic distances of species found. The Kimura-2-Parameters genetic distance related to the Neighbor-Joining method with 1000 pseudoreplicates using MEGA v6.0 software. Sustainability values of the branches are presented next to the nodes at each fork; values below 70\% were hidden. The group names in italics indicate the lowest possible taxonomic level, and absolute abundance is indicated in parentheses. (*) Species for which sequences are not deposited in BOLD.
The Tibagi River and its sub-tributary (Congonhas River) presented a smaller diversity of species (11), representing $44 \%$ of the total identified. Eggs of Leporellus vittatus, Iheringichthys labrosus, Triportheus nematurus, Pimelodus microstoma, Leporinus friderici, and Pimelodus maculatus were found in both the Tibagi River and the Cinzas River. For both tributaries, the abundance and richness of native and migratory species overlapped with three non-native species identified; Triportheus nematurus, $\mathrm{Me-}$ galeporinus macrocephalus, and Sorubim lima; the latter two found only in the Cinzas River. For the native species, the abundance of the short-distance migratory species Pimelodus maculatus stands out, totaling 374 of the total eggs identified (40.3\%).

\section{Discussion}

The differential of the present study is the analysis of fish eggs, where identification by morphological characters is not possible in most cases due to the size and interspecific similarities (Richards, 2005). By identifying almost $100 \%$ of the samples, this study is relevant, since fish egg identification analyses are scarce, particularly in the freshwater environment of the Neotropical region (Oliveira and Ferreira, 2008; Hermes-Silva et al., 2009; Frantine-Silva et al., 2015), since the majority of works are focused on the marine environment (Shao et al., 2002; Burghart et al., 2014; Harada et al., 2015; Hubert et al., 2015; Lin et al., 2016; Hofmann et al., 2017; Rodrigues et al., 2018). Correct identification of fish eggs is crucial for recognizing and protecting breeding areas of commercially important species, as well as endangered species (Valdez-Moreno et al., 2010).

Analysis of the sequences resulted in specific identification of $99.78 \%$ of the samples. This level of efficacy was also obtained in other studies using the same methodology for identifying reproductive fish products (García-Dávila et al., 2014, 2015; Becker et al., 2015; Frantine-Silva et al., 2015; Hubert et al., 2015; Rodigues et al., 2018). The accuracy of species identification using the DNA barcode technique depends on the presence of high-quality reference sequences available in databases such as GenBank and BOLD Systems (Becker et al., 2015). Thus, the optimal egg identification rate obtained at the species level is due to the fact that the upper Paraná River basin has a large barcode data set available for its ichthyofauna (Pereira et al., 2013).

Two major studies carried out with ichthyoplankton in several reservoirs of the Paranapanema River demonstrated good identification efficiency using the DNA barcode method. Frantine-Silva et al. (2015) were able to identify $99.81 \%$ of a total of 536 samples and Lima (2015) was able to identify $88.44 \%$ of a total of 961 samples. The current study identified 928 eggs from the Cinzas and Tibagi Rivers, the main tributaries of the Capivara reservoir, during three piracema periods. In addition, the results contributed six new species not yet identified in previous studies by Lima (2015) and Frantine-Silva et al. (2015), such as: Astyanax schubarti, Characidium zebra, Leporellus vittatus, Leporinus striatus, Pseudopimelodus mangurus, and Steindachnerina 
Table 1 - Table of species distribution in the Capivara reservoir tributaries.

\begin{tabular}{|c|c|c|c|c|c|c|}
\hline \multicolumn{7}{|l|}{ HPP Capivara } \\
\hline Species & $\%$ & $\mathbf{N}$ & BC & MC & CO & TI \\
\hline \multicolumn{7}{|l|}{ Characiformes } \\
\hline \multicolumn{7}{|l|}{ Anostomidae } \\
\hline Leporellus vittatus (Valenciennes, 1850) & 0.32 & 3 & 2 & & & 1 \\
\hline Leporinus friderici (Bloch, 1794) & 17.7 & 164 & 44 & 22 & & 98 \\
\hline Leporinus octofasciatus Steindachner, 1915 & 0.1 & 1 & & & & 1 \\
\hline Leporinus striatus Kner, 1858 & 0.22 & 2 & 1 & 1 & & \\
\hline Megaleporinus macrocephalus Garavello \& Britski, $1988 \dagger$ & 1.94 & 18 & 18 & & & \\
\hline Megaleporinus obtusidens (Valenciennes, 1837) & 0.86 & 8 & 8 & & & \\
\hline Megaleporinus piavussu Britski, Birindelii \& Garavello, 2012 & 0.22 & 2 & 1 & 1 & & \\
\hline \multicolumn{7}{|l|}{ Characidae } \\
\hline Astyanax lacustris (Lütken, 1875) & 0.53 & 5 & 5 & & & \\
\hline Astyanax schubarti Britski, 1964 & 0.1 & 1 & 1 & & & \\
\hline \multicolumn{7}{|l|}{ Crenuchidae } \\
\hline Characidium zebra Eigenmann, 1909 & 0.1 & 1 & & 1 & & \\
\hline \multicolumn{7}{|l|}{ Curimatidae } \\
\hline Cyphocharax nagelii (Steindachner, 1881) & 0.75 & 7 & 7 & & & \\
\hline Steindachnerina insculpita (Fernández-Yépez, 1948) & 0.1 & 1 & 1 & & & \\
\hline \multicolumn{7}{|l|}{ Parodontidae } \\
\hline Apareiodon affinis (Steindachner, 1879) & 0.32 & 3 & & & & 3 \\
\hline \multicolumn{7}{|l|}{ Prochilodontidae } \\
\hline Prochilodus lineatus (Valenciennes, 1837) & 0.1 & 1 & 1 & & & \\
\hline \multicolumn{7}{|l|}{ Serrasalmidae } \\
\hline Piaractus mesopotamicus (Holmberg, 1887) & 0.22 & 2 & 1 & 1 & & \\
\hline \multicolumn{7}{|l|}{ Triportheidae } \\
\hline Triportheus nematurus (Kner, 1858)† & 5.92 & 55 & 13 & 15 & 23 & 4 \\
\hline \multicolumn{7}{|l|}{ Siluriformes } \\
\hline \multicolumn{7}{|l|}{ Heptapteridae } \\
\hline Heptapteridae & 0.22 & 2 & 1 & 1 & & \\
\hline \multicolumn{7}{|l|}{ Pimelodidae } \\
\hline Iheringichthys labrosus (Lütken, 1874) & 0.53 & 5 & 1 & & & 4 \\
\hline Megalonema platanum (Günther, 1880) & 0.1 & 1 & & & & 1 \\
\hline Pimelodus maculatus Lacepède, 1803 & 40.3 & 374 & 219 & 17 & & 138 \\
\hline Pimelodus microstoma Steindachner, 1877 & 12.5 & 116 & 74 & 4 & & 38 \\
\hline Pimelodus sp. & 7.87 & 73 & & & & 73 \\
\hline Pinirampus pirinampu (Spix \& Agassiz, 1829) & 1.7 & 16 & & & & 16 \\
\hline Pseudoplatystoma corruscans (Spix \& Agassiz, 1829) & 1.7 & 16 & 16 & & & \\
\hline Sorubim lima $($ Bloch \& Schneider, 1801)† & 5.06 & 47 & 32 & 15 & & \\
\hline \multicolumn{7}{|l|}{ Pseudopimelodidae } \\
\hline Pseudopimelodus mangurus (Valenciennes, 1835): & 0.43 & 4 & 4 & & & \\
\hline
\end{tabular}

Subtitle: (December 2012 to March 2015). (\%): Relative frequency for each species (N): Absolute frequency, by collection point. LC: lower Cinzas; MC: middle Cinzas; CO: Congonhas River; and LT: lower Tibagi. †Endangered species (Abilhoa \& Duboc, 2004).†Species non-native to the upper Paraná River (Júlio Jr et al., 2009).

insculpta. Nineteen of the 25 species identified in the current study were also found by Frantine-Silva et al. (2015) and Lima (2015) in the tributaries of the Capivara Reservoir, the Cinzas and Tibagi Rivers. Therefore, the total species identified by DNA barcode considering all analyzes in the Paranapanema River corresponds to approximately $29.8 \%$ of the species richness documented for this region (225) (Jarduli et al., 2020).
Only two samples presented non-specific correspondence, with mean similarity of $91.62 \%$, being classified only at the family level. This low similarity is probably associated with the great diversity of the Neotropical region, where it is common that some species have not yet have been adequately validated and deposited, as the region has very rich and diverse ichthyofauna, and although many species have already been described, many still await description 

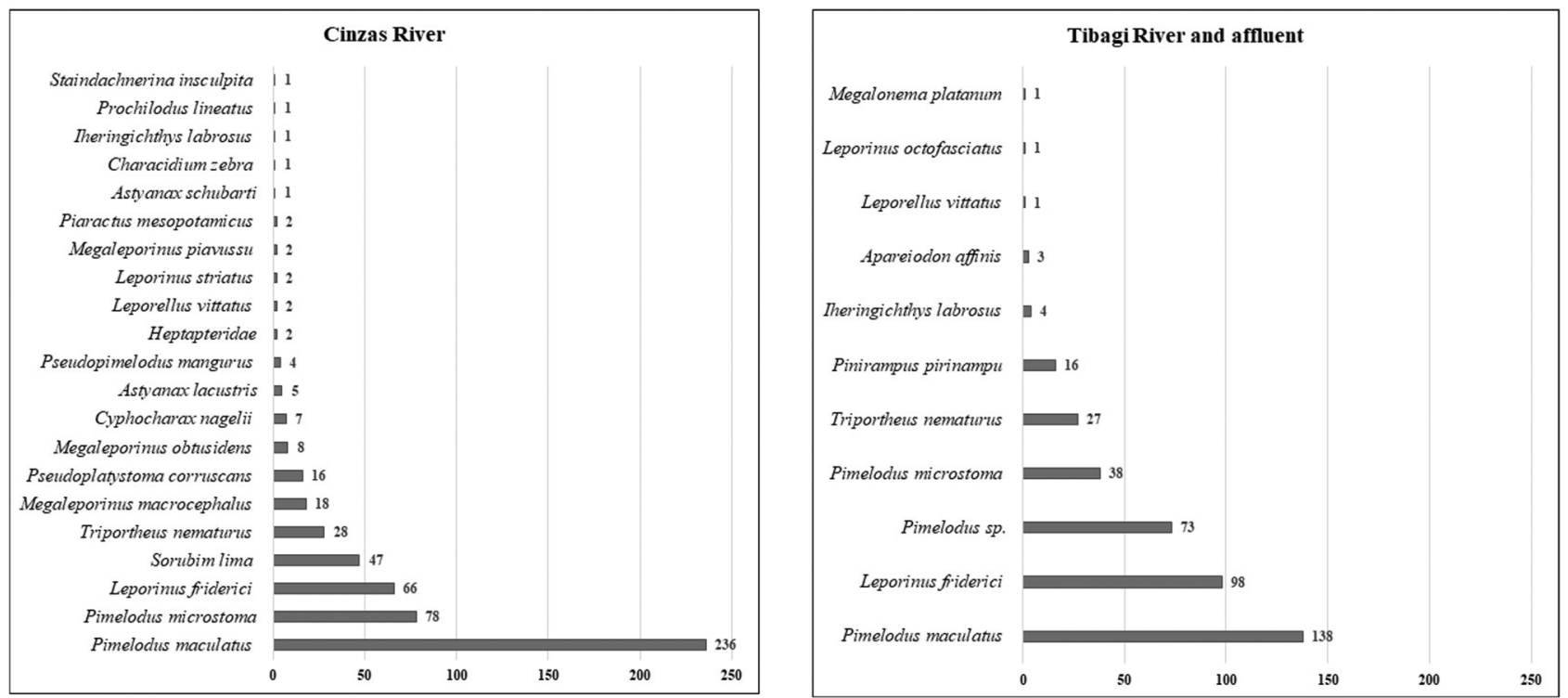

Figure 3 - Species found for each tributary: Cinzas River and Tibagi River, numbers in the bars indicate the number of specimens.

(Levêque et al., 2007; Albert and Reis, 2011; Toussaint et al., 2016). Except for these two individuals, the other samples were able to be identified at a specific level with high reliability, including taxa with complex taxonomic identification, as in the case of the genus Astyanax and family Anostomidae, which can easily be misidentified using traditional taxonomic methods, even in adult individuals (Garavello and Britski, 2003; Bertaco and Garutti, 2007). Two species belonging to the genus Astyanax: Astyanax lacustris and Astyanax schubarti and seven species of the family Anostomidae: Leporellus vittatus, Leporinus friderici, Leporinus octofasciatus, Leporinus striatus, Megaleporinus macrocephalus, Megaleporinus obtusidens, and Megaleporinus piavussu were identified with a high match to specimens deposited in the database (>99\%) (Table S1).

Several factors influence the distribution patterns and structure of fish assemblages, as each species selects a spawning site based on a set of biotic and abiotic characteristics such as location, period, temperature, and duration and reproductive intensity of adults. Thus, to ensure a sufficient number of survivors, fish usually need adequate conditions to reproduce (Bialetzki et al., 2005; Baumgartner et al., 2008). However, environments influenced by dams lack the ideal conditions for the survival and reproduction of many South American fish species (Agostinho and Gomes, 2005; Agostinho et al., 2008). Studies carried out on the Paranapanema River show that the tributaries present greater species richness than the reservoirs (Frantine-Silva et al., 2015; Lima, 2015).

In the current study, reproductive products of 25 species were identified, among them 15 native species with reproductive displacement, which may carry out short migrations, such as: Astyanax altiparanae (Vazzoler, 1996), Leporinus friderici, Apareiodon affinis, Iheringichthys labrosus, Steindachnerina insculpta (Agostinho et al., 2003), Leporinus octofasciatus, (Duke Energy, 2008) Astyanax schubarti, Pimelodus maculatus, and Cyphocharax nagelii
(Suzuki et al., 2004). Long-distance migrants were also identified: Piaractus mesopotamicus, Prochilodus lineatus, Pseudoplatystoma corrusccans, Pinirampus pirinampu (Agostinho et al., 2003), and Leporinus obtusidens (Suzuki et al., 2004). To complete their life cycles, long-distance migratory species require a habitat with the necessary conditions for spawning, development, and growth (Agostinho et al., 2008; Pelicice et al., 2015).

According to Shibatta et al. (2007), river fragmentation due to the construction of dams prevents many migratory and rheophilic fish species from completing the reproductive process. Analyzing fish eggs and larvae, Baumgartner et al. (2008) observed evidence of intense reproductive activities of migratory fish in tributaries of the Paraná River. The authors pointed out that the presence of tributaries free of dams plays a fundamental role in the maintenance of rheophilic species and provides conditions for the drift of eggs and larvae, making them important for maintaining regional ichthyofaunistic diversity.

Studying reproductive activities in the Capivara reservoir, Orsi (2010) found that among the points studied, reproductive activity was more intense in the stretches of the Tibagi and Cinzas Rivers, with semilotic and lotic characteristics respectively. The rheophilic and migratory species are highlighted, indicating a strong influence of tributaries in the reproduction of these fish species. This intense reproductive activity must also be associated with the environmental characteristics of these tributaries, such as the presence of macrophyte banks, submerged trunks, and forest remnants, as well as the occurrence of marginal lagoons. In the present study, more than half of the species identified $(60 \%)$ have a habit of reproductive displacement, indicating that the tributaries of this reservoir are being used as a spawning site by these species, making the preservation of these areas essential for the maintenance of the local ichthyofauna. The highest abundance was observed for Pimelodus maculatus (representing $40.30 \%$ of the captures), which may be related to its better 
adjustment to reservoir conditions than other species (Frantine-Silva et al., 2015).

Among the 1,497 samples of reproductive products (eggs and larvae) processed in Paranapanema river reservoirs by Lima (2015) and Frantine-Silva et al. (2015), the presence of Pseudopimelodus mangurus, a rare and endangered species, had not been observed. In total, four P. mangurus eggs were identified in our analyses, all from the lower Cinzas River locality. Frantine-Silva et al. (2015) found another endangered species in the same location, Steindachneridion scriptum (Abilhoa and Duboc, 2004), and appointed this region as a critical point for species conservation. For the Cinzas River, it is also worth mentioning the presence of a large number of fish eggs of commercial importance, found in low frequency in the Paranapanema River, such as the Piaractus mesopotamicus, popularly known as Pacu, and Pseudoplatystoma corruscans known as Pintado (Kubitza, 1998; Hilsdorf and Marques, 2006; Duke Energy, 2008). The latter is found in the Red Book of Threatened Fauna of Paraná in the category of near threatened (Abilhoa and Duboc, 2004). The presence of eggs of this species indicates that these fish are using the tributary during their reproductive cycle. The Cinzas River presented higher species richness than the Tibagi River, which was also observed in the work of Frantine-Silva et al. (2015). According to Hoffmann et al. (2005), the Cinzas River is the environment farthest from the lacustrine zone of the reservoir, being less influenced by the dam, and presenting characteristics more similar to the original environment. Thus, this stretch is of prime importance for the Capivara reservoir in terms of species maintenance.

The Tibagi River is the largest tributary of the reservoir and second largest stretch with respect to diversity and has been pointed out by several studies as responsible for maintaining diversity (Shao et al., 2002; Hoffmann et al., 2005). This river presented species of short and long reproductive displacement, indicating it as an alternative route to complete reproductive cycles. Among these species, eggs of Pinirampus pirinampu were found, a large species with long reproductive displacement which, according to Dias et al. (2004) uses the Capivara reservoir as a place of growth and food but chooses the lotic environments of its main tributaries as a breeding area. In addition, the presence of Megalonema platanum was also observed, a rare species in the Paraná River basin and a species for which little information is reported about its biology. For the Congonhas River, a tributary of the Tibagi River, only one species was found, Triportheus nematurus. However, this result is probably due to the small number of sampled eggs collected at this point, since this tributary still maintains adequate conditions that favor the conservation of fish including native and migratory species (Garcia et al., 2019).

Eggs from species not native to the basin were found in both tributaries, although a relatively small number of samples and species. Triportheus nematurus was present in both tributaries while Sorubim lima and Megaleporinus macrocephalus were found only in the Cinzas River. These three species are alien species and, according to Júnior et al. (2009), originate from invasion after the construction of the Itaipu reservoir. Although Megaleporinus macrocephalus and Triportheus nematurus dispersed due to the elimination of the Seven Falls barrier, the removal of obstacles was not the only reason for their introduction. Megaleporinus macrocephalus was heavily restocked (Agostinho et al., 2007), with leaks recorded from aquaculture tanks during flooding (Orsi and Agostinho, 1999). Similarly, the species Triportheus nematurus was intensively introduced for restocking purposes in several reservoirs located in the upper Paraná River basin (CESP, 1996).

In conclusion, the results obtained demonstrated that the DNA barcode was fundamental for the identification of species of fish egg samples, aggregating information regarding the reproductive biology of fish species present in two important tributaries of a basin impacted by cascading reservoirs. Therefore, we recommend using this technique in studies of fish eggs for future conservation plans.

\section{Acknowledgments}

The authors wish to thank the team of the Laboratorio de Ecologia de Peixes e Invasões Biológicas (LEPIB) for their help with the execution of the sampling process and selection of the material. This research was funded by a grant from the Coordenação de Aperfeiçoamento de Pessoal de Nível Superior (CAPES)

\section{Conflict of Interest}

The authors have no conflicts of interest to declare.

\section{Author Contributions}

FSA and MCCL conceived and designed the study; MLO collected the samples; MCCL, SCL, and CSS performed the analysis; MCCL and KMS wrote the manuscript and designed the figures, all authors read and approved the final version.

\section{References}

Abilhoa V and Duboc L (2004) Peixes - água doce. In: Mikich SB and Bérnils RS (eds). Livro vermelho da fauna ameaçada do Estado do Paraná. Instituto Ambiental do Paraná, Curitiba, pp 581-682.

Agostinho AA and Gomes LC (2005) O manejo da pesca em reservatórios da bacia do Alto rio Paraná: avaliação e perspectivas. In: Nogueira MG, Henry R and Jorcin A (eds) Ecologia de reservatórios: impactos potenciais, ações de manejo e sistemas em cascata. Rima Editora, São Carlos, pp 23-55.

Agostinho AA, Gomes L, Suzuki H and Julio Jr HF (2003) Migratory fishes of the upper Paraná River basin, Brazil. In: Carolsfeld J, Harvey B, Baer A and Ross C (eds) Migratory fishes of South America: Biology, fisheries and conservation status. World Fisheries Trust, Victoria, pp 19-99.

Agostinho AA, Pelicice F, Petry A, Gomes L and Júlio Jr H (2007) Fish diversity in the upper Paraná River basin: Habitats, fisheries, management and conservation. Aquat Ecosyst Health Manag 10:174-186. 
Agostinho AA, Pelicice FM and Gomes LC (2008) Dams and the fish fauna of the Neotropical region: Impacts and management related to diversity and fisheries. Braz J Biol 68:11191132 .

Albert JS and Reis R (2011) Historical biogeography of Neotropical freshwater fishes. University of California Press, Berkeley, $388 \mathrm{p}$.

Baumgartner G, Nakatani K, Gomes LC, Bialetzki A, Sanches PV and Makrakis MC (2008) Fish larvae from the upper Paraná River: Do abiotic factors affect larval density? Neotrop Ichthyol 6:551-558.

Becker R, Sales NG, Santos G, Santos G and Carvalho D (2015) DNA barcoding and morphological identification of neotropical ichthyoplankton from the Upper Paraná and São Francisco. J Fish Biol 87:159-168.

Bertaco VA and Garutti V (2007) New Astyanax from the upper rio Tapajós drainage, central Brazil (Characiformes: Characidae). Neotrop Ichthyol 5:25-30.

Bialetzki A, Nakatani K, Sanches PV, Baumgartner G and Gomes LC (2005) Larval fish assemblage in the Baía River (Mato Grosso do Sul State, Brazil): Temporal and spatial patterns. Environ Biol Fishes 73:37-47.

Burghart SE, Van Woudenberg L, Daniels CA, Meyers SD, Peebles EB and Breitbart M (2014) Disparity between planktonic fish egg and larval communities as indicated by DNA barcoding. Mar Ecol Prog Ser 503:195-204.

CESP - Companhia Energética de São Paulo (1996) Aspectos limnológicos, ictiológicos e pesqueiros de reservatórios da CESP no Período de 1986 a 1994. CESP, São Paulo, 81 p.

Dias J, Britto S, Vianna N and Garavello J (2004) Biological and ecological aspects of Pinirampus pirinampu (Spix, 1829), Siluriformes, Pimelodidae. Capivara reservoir, Paranapanema River, Southern Brazil. Acta Lim Bras 16:293-304.

Dudgeon D, Arthington AH, Gessner MO, Kawabata ZI, Knowler DJ, Lévêque C, Naiman RJ, Prieur-Richard AH, Soto D and Stiassny ML (2006) Freshwater biodiversity: Importance, threats, status and conservation challenges. Biol Rev 81:163182.

Duke Energy Geração Paranapanema (2008) Peixes do rio Paranapanema. 2nd edition. Horizonte Geográfico, São Paulo, 63 p.

Edgar RC (2004) MUSCLE: Multiple sequence alignment with high accuracy and high throughput. Nucleic Acids Res 32:1792-1797.

Frantine-Silva W, Sofia S, Orsi M and Almeida F (2015) DNA barcoding of freshwater ichthyoplankton in the Neotropics as a tool for ecological monitoring. Mol Ecol Res 15:1226-1237.

Garavello J and Britski H (2003) Family Anostomidae (Headstanders). In: Reis RE, Kullander SO and Ferraris Jr. (eds.) Checklist of the Freshwater Fishes of South and CJ (eds). EDIPUCRS, Porto Alegre, pp 71-84.

Garcia DAZ, Vidotto-Magnoli AP, Costa ADA, Casimiro ACR, Jarduli LR, Ferraz JD, De Almeida FS and Orsi ML (2019) Importance of the Congonhas River for the conservation of the fish fauna of the Upper Paraná basin, Brazil. Biodiversitas J Biol Diversity 20:474-481.

García-Dávila C, Castro-Ruiz D, Renno JF, Chota-Macuyama W, Carvajal-Vallejos F, Sanchez H, Angulo C, Nolorbe C, Alvarado J and Estivals G (2015) Using barcoding of larvae for investigating the breeding seasons of Pimelodid catfishes from the Marañon, Napo and Ucayali rivers in the Peruvian Amazon. J Appl Ichthyol 31:40-51.

García-Dávila CR, Castro-Ruiz D, Sáchez-Ribeiro H, Ismiño-Orbe RA, Rengifo-Trigoso D, García-Vásquez A, Tello-Martín JS, Cota-macuyama W, Duponchele F and Renno JF (2014) Di- versidad de ictioplanctonen los ríos Curaray, Arabela y Napo (Amazonía peruana). Folia Amazón 23:67-78.

Gleason LU and Burton RS (2012) High-throughput molecular identification of fish eggs using multiplex suspension bead arrays. Mol Ecol Res 12:57-66.

Harada AE, Lindgren EA, Hermsmeier MC, Rogowski PA, Terrill $\mathrm{E}$ and Burton RS (2015) Monitoring spawning activity in a southern California marine protected area using molecular identification of fish eggs. PLoS One 10:e0134647.

Hebert PD, Cywinska A, Ball SL and Dewaard JR (2003) Biological identifications through DNA barcodes. Proc Biol Sci. 270:313-321.

Hermes-Silva S, Reynalte-Tataje D and Zaniboni-Filho E (2009) Spatial and temporal distribution of ichthyoplankton in the upper Uruguay river, Brazil. Braz Arch Biol Tech 52:933944.

Hilsdorf AR, Resende EK and Marques D (2006) Genética e conservação de estoques pesqueiros de águas continentais no Brasil: situação atual e perspectivas. Embrapa, Brasília, 43 p.

Hoffmann AC, Orsi ML and Shibatta OA (2005) Diversidade de peixes do reservatório da UHE Escola Engenharia Mackenzie (Capivara), Rio Paranapanema, bacia do alto rio Paraná, Brasil, e a importância dos grandes tributários na sua manutenção. Iheringia Sér Zool 95:319-325.

Hofmann T, Knebelsberger T, Kloppmann M, Ulleweit J and Raupach M (2017) Egg identification of three economical important fish species using DNA barcoding in comparison to a morphological determination. J Appl Ichthyol 33:925-932.

Hubert N, Hanner R, Holm E, Mandrak NE, Taylor E, Burridge M, Watkinson D, Dumont P, Curry A and Bentzen P (2008) Identifying Canadian freshwater fishes through DNA barcodes. PLoS One 3:e2490.

Hubert N, Espiau B, Meyer C and Planes S (2015) Identifying the ichthyoplankton of a coral reef using DNA barcodes. Mol Ecol Res 15:57-67.

Jarduli LR, Garcia DAZ, Vidotto-Magnoni AP, Casimiro ACR, Vianna NC, Almeida FS, Jerep FC and Orsi ML (2020) Fish fauna from the Paranapanema River basin, Brazil. Biota Neotrop 20:e20180707.

Júnior J, Ferreira H, Tós CD, Agostinho ÂA and Pavanelli CS (2009) A massive invasion of fish species after eliminating a natural barrier in the upper rio Paraná basin. Neotrop Ichthyol 7:709-718.

Kimura M (1980) A simple method for estimating evolutionary rates of base substitutions through comparative studies of nucleotide sequences. J Mol Evol 16:111-120.

Kubitza F (1998) Produção intensiva no Projeto Pacu Ltda. e Agropeixe Ltda. Panor aquic 8:41-50.

Lévêque C, Oberdorff T, Paugy D, Stiassny MLJ and Tedesco PA (2007) Global diversity of fish (Pisces) in freshwater. In: Balian EV, Lévêque C, Segers H and Martens K (eds) Freshwater animal diversity assessment. Springer, Heidelberg, pp. $545-567$.

Lima SC (2015) Identificação molecular e variação temporal de ovos e larvas de peixes (Teleostei: Osteichthyes) em zonas de influência de reservatórios no rio Paranapanema. M. Sc. Thesis, Universidade Estadual de Londrina, Paraná.

Lin HY, Chiu MY, Shih YM, Chen IS, Lee MA and Shao KT (2016) Species composition and assemblages of ichthyoplankton during summer in the East China Sea. Cont Shelf Res 126:64-78.

Lopes CM, Almeida FS, Orsi ML, Britto SGC, Sirol RN and Sodré LMK (2007) Fish passage ladders from Canoas ComplexParanapanema River: Evaluation of genetic structure mainte- 
nance of Salminus brasiliensis (Teleostei: Characiformes). Neotrop Ichthyol 5:131-138.

Nakatani K, Baumgartner G and Cavicchioli M (1997) Ecologia de ovos e larvas de peixes. In: Vazzoler AEAM, Agostinho AA and Hahn NS (eds) A planície de inundação do alto rio Paraná: aspectos físicos, biológicos e socioeconômicos. EDUEM, Maringá, pp. 281-306.

Nakatani K, Agostinho AA, Baumgartner G, Bialetzki A, Sanches PV, Makrakis MC and Pavanelli CS (2001) Ovos e larvas de peixes de água doce: desenvolvimento e manual de identificação. EDUEM, Maringá, 378 p.

Nei M and Kumar S (2000) Molecular Evolution and Phylogenetics. Oxford University Press, Oxford, 333 p.

Oliveira EC and Ferreira EJ (2008) Spawning areas, dispersion and microhabitats of fish larvae in the Anavilhanas Ecological Station, Rio Negro, Amazonas State, Brazil. Neotrop Ichtyol 6:559-566.

Orsi ML (2010) Estratégias reprodutivas de peixes da região média-baixa do rio Paranapanema, Reservatório de Capivara. Blucher Acadêmico, São Paulo, 115 p.

Orsi ML and Agostinho A (1999) Introdução de espécies de peixes por escapes acidentais de tanques de cultivo em rios da Bacia do Rio Paraná, Brasil. Rev Bras Zoo 16:557-560.

Orsi ML, Almeida FS, Swarça AC, Claro-García A, Vianna NC, Garcia DAZ and Bialetzki A (2016) Ovos, larvas e juvenis dos peixes da Bacia do Rio Paranapanema uma avaliação para a conservação. Triunfal Gráfica e Editora, São Paulo, 136 p.

Pegg GG, Sinclair B, Briskey L and Aspden WJ (2006) MtDNA barcode identification of fish larvae in the southern Great Barrier Reef-Australia. Sci Mar 70:7-12.

Pelicice FM, Pompeu PS and Agostinho AA (2015) Large reservoirs as ecological barriers to downstream movements of Neotropical migratory fish. Fish Fish 16:697-715.

Pereira LH, Hanner R, Foresti F and Oliveira C (2013) Can DNA barcoding accurately discriminate megadiverse Neotropical freshwater fish fauna? BMC Genet 14:20.

Ratnasingham S and Hebert PD (2007) bold: The Barcode of Life Data System (http://www.barcodinglife.org). Mol Ecol Notes 7:355-364.

Richards WJ (2005) Early stages of Atlantic fishes: an identification guide for the western central north Atlantic. CRC Press, Boca Raton, vol. 2, 1824 p.

Rodrigues T, Hilsdorf AWS, Pimenta EG and de Amorim AF (2018) Ocorrência e identificação de larvas de Istiophoridae e ovos de Xiphiidae na costa sudeste brasileira. Bol Inst Pesca 43:78-86.

Shao KT, Chen KC and Wu JH (2002) Identification of marine fish eggs in Taiwan using light microscopy, scanning electric microscopy and mtDNA sequencing. Mar Freshw Res 53:355365 .
Shibatta OA, Gealh AM and Bennemann ST (2007) Ictiofauna dos trechos alto e médio da bacia do rio Tibagi, Paraná, Brasil. Biota Neotrop 7:125-134.

Stoeckle M (2003) Taxonomy, DNA, and the barcode of life. BioScience 53:796-797.

Strayer DL and Dudgeon D (2010) Freshwater biodiversity conservation: recent progress and future challenges. J North Am Benthol Soc 29:344-358.

Suzuki HI, Vazzoler A, Marques EE, Lizama MP and Inada P (2004) Reproductive ecology of the fish assemblages. In: Thomaz S M, Agostinho AA and Hahn NS (eds) The Upper Paraná River and its floodplain: physical aspects, ecology and conservation. Backhuys Publishers, Leiden, pp 271-291.

Tamura K, Stecher G, Peterson D, Filipski A and Kumar S (2013) MEGA6: Molecular Evolutionary Genetics Analysis version 6.0. Mol Biol Evol. 30:2725-2729.

Togawa RC and Brígido MM (2003) PHP: Web based tool for simple electropherogram quality analysis. In: 1st International Conference on Bioinformatics and Computational Biology, Ribeirão Preto.

Toussaint A, Charpin N, Brosse S and Villéger S (2016) Global functional diversity of freshwater fish is concentrated in the Neotropics while functional vulnerability is widespread. Sci Rep 6:22125.

Valdez-Moreno M, Vásquez-Yeomans L, Elías-Gutiérrez M, Ivanova NV and Hebert PDN (2010) Using DNA barcodes to connect adults and early life stages of marine fishes from the Yucatan Peninsula, Mexico: Potential in fisheries management. Mar Freshw Res 61:655-671.

Vazzoler AEAM (1996) Biologia da reprodução de peixes teleósteos: Teoria e prática. Eduem, Maringá,169 p.

Vianna N and Nogueira M (2008) Ichthyoplankton and limnological factors in the Cinzas River-an alternative spawning site for fishes in the middle Paranapanema River basin, Brazil. Acta Limnol Bras 20:139-151.

Ward RD, Hanner R and Hebert PD (2009) The campaign to DNA barcode all fishes, FISH-BOL. J Fish Biol 74:329-356.

Ward RD, Zemlak TS, Innes BH, Last PR and Hebert PD (2005) DNA barcoding Australia's fish species. Philos Trans R Soc Lond B Biol Sci 360:1847-1857.

Waugh J (2007) DNA barcoding in animal species: Progress, potential and pitfalls. Bioessays 29:188-197.

\section{Supplementary Material}

The following online material is available for this article: Figure S1 - Egg morphotypes defined a priori.

Table S1 - Species identified from eggs from the main tributaries of the Capivara reservoir.

\section{Associate Editor: Vera Maria Fonseca de Almeida e Val}

License information: This is an open-access article distributed under the terms of the Creative Commons Attribution License (type CC-BY), which permits unrestricted use, distribution and reproduction in any medium, provided the original article is properly cited. 